ISSN: 2617-6548

\title{
Changing Brown Cities to Smart and Sustainable ones: Proposed Applicable Strategies and Indicators for Omid-e-Sabz Township in Kabul City
}

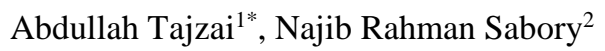 \\ 1,2 Department of Energy Engineering, Faculty of Engineering, Kabul University, Kabul, Afghanistan \\ *Corresponding author: Abdullah Tajzai (abdullah.tajzai.10@gmail.com)
}

\begin{abstract}
The two world-wide challenges, the population growth and the climate change, have forced everyone to think differently and seek new approaches to revive cities to be sustainable for centuries to come. Therefore, transforming the cities to the green and smart city are inevitable. The first step towards green and smart city is the recognition of applicable indicators for an existing city. In the next stage, introducing the most sustainable strategies to implement and realize the introduced indicators are of key importance. Omid-e-Sabz is a crowded city in the south-west of Kabul, hosts more than 27,000 inhabitants. Thus, a study through modifying this city to a sustainable and smart city is crucial for future urban development in Afghanistan. The indicators of green and smart city have been analyzed for Omid-e-Sabz Town in this paper. Moreover, some key guidance's and plans for transforming an ordinary city to sustainable and smart city have been introduced and suggested. This paper is the first of its kind that discusses this important topic for Afghanistan. It will help the urban planning sector of Afghanistan to learn and continue this discourse to make sure the future cities in Afghanistan are smart and sustainable.
\end{abstract}

Keywords: Smart City, Kabul City, Climate Change, Energy and Environment.

DOI: 10.53894 /ijirss.v4i2.57

Funding: This study received no specific financial support.

History: Received: 13 January 2021/Revised: 18 February 2021/Accepted: 20 March 2021/Published: 30 March 2021

Licensed: This work is licensed under a Creative Commons Attribution 4.0 License (oc) EY

Acknowledgement: Both authors contributed to the conception and design of the study.

Competing Interests: The authors declare that they have no conflict of interests.

Transparency: The authors confirm that the manuscript is an honest, accurate, and transparent account of the study was reported; that no vital features of the study have been omitted; and that any discrepancies from the study as planned have been explained.

Ethical: This study follows all ethical practices during writing.

\section{Introduction}

Afghanistan doesn't have a centralized grid network. Therefore, it has three major grid islands, which are North East Power System (NEPS), South East Power System (SEPS), and West Power System (WPS). NEPS demand 
power is $900 \mathrm{MW}$, while the supply power is $600 \mathrm{MW}$. Furthermore, the SEPS and WPS demand powers are 100 and $220 \mathrm{MW}$, yet the supply powers are 45 and $180 \mathrm{MW}$ [2]. At the beginning of 2021, Kabul city peak demand reached $750 \mathrm{MW}$, whereas the supply power was $477 \mathrm{MW}$ [3]. Therefore, Kabul inhabitants use dirty sources of energy for energy usage during winter due to lack of access to clean energy and poverty. This problem forces us to investigate on the alternative solution for Kabul city, which sustainable and smart city is one of them. We have taken a town as a sample for studying the smart and sustainable cities in the Kabul. For this reason, we picked Omid-eSabz Township for this study. Omid-e-Sabz map has been shown in the Figure 1.

Omid-e-Sabz Town pla

ced south-west of Kabul City at $3 \mathrm{~km}$ of Darla-man palace. It has an area of around 3 square kilometers. $50 \%$ of the land is used for residential areas, and the other $50 \%$ used to construct roads, fields, green spaces, and public access. This town is house for 27,500 inhabitants [1]. In this town, four transformers had installed that every transformer has $800 \mathrm{kVA}$ capacity, which makes the total installed capacity of 3,200 kVA of electricity. According to Dabs, the peak demand of this town was 2.392 MVA in 2015.and the electricity consumption from the grid was 795.914 MWh/2-month in 2015 for 1,180 consumers [4].

\section{Literature Review}

Sustainable and smart cities are distinctive and massive concepts; however, each has similarities. If they both mix, it will give a clean and high intelligent city once. The cities like Singapore carry out each sustainable and smart city separately. More than half of the world's population now lives in cities, and this proportion is going to grow to seventy-five percentages by 2050 [5]. In recent times, the most urbanized regions are Northern America (82 \%), Latin America and the Caribbean (80\%), and Europe (73\%) [5]. The green city has the subsequent objectives: clean air and water, the risk of main infectious disease outbreaks in such cities is low, low chemical and physical hazards, exceptional streets and parks, and green cities are resilient within the face of natural disasters [5]. Green cities additionally encourage green behavior, along with the usage of public transit, decrease transfers of environmental expenses to areas outside the city, make certain development towards sustainable consumption, and their ecological influences are notably small [5].

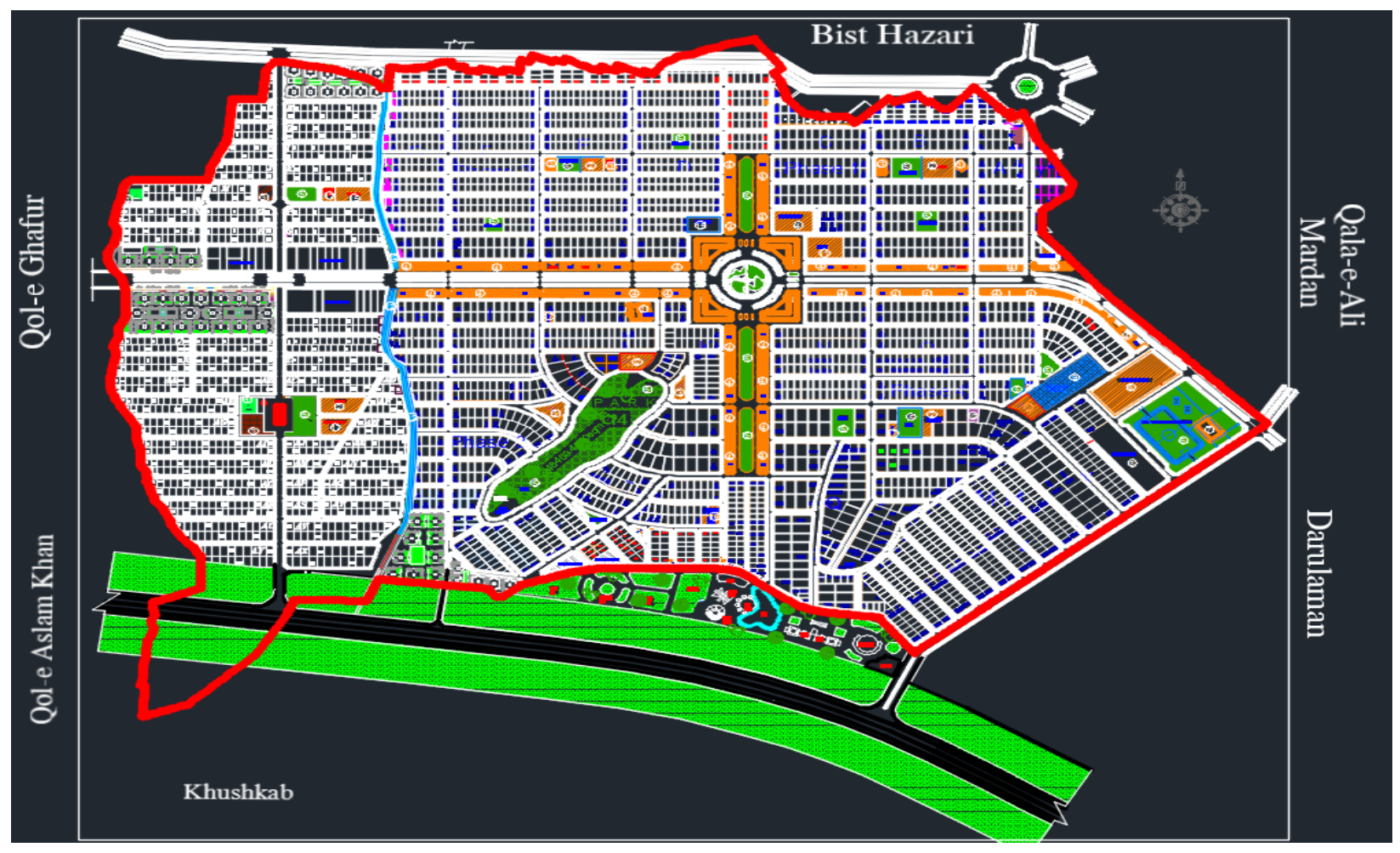

Figure-1.

Omid-e-Sabz Town Map. [1] 
On the other hand, Smart city is looking to discuss public problems through information and communications technology (ICT) based solutions on the base of multi-stakeholder and municipality-based partnership [6]. It makes integrating the physical, social, IT, and business infrastructures into one framework, therefore, as to leverage the collective intelligence of a city [6]. The smart city monitors and integrates conditions of all its crucial infrastructure - consisting of roads, bridges, tunnels, rails, subways, airports, seaports, communications, water, electricity, even major buildings [7]. It can better optimize its resources, plan its preventive maintenance activities, and check security aspects while maximizing services to its residents. The smart city makes use of ICT to enhance its livability, workability, and sustainability [7].

Smart city has six dimensions, which are being built at the smart combination of endowments and activities of selfdecisive, independent, and conscious citizens [8]. The smart economy, smart government, smart environment, smart living, smart mobility, and smart people are smart city wheels. A worldwide and European agreement on smart city indicators has not been determined because smartness is not always easily measurable [8]. The indicators, which stated at the international papers or used in cities for projects have existed greater than four hundred that smart environment has 86 indicators, smart Living has 72 indicators, smart people have 68 indicators, smart mobility has 77 indicators, the smart economy has 55 indicators, and the smart government has 69 indicators [9]. Sustainable city indicators are equipment, which allows city planners, city managers, and policymakers to decide the socio-economic and environmental impact like current urban designs, infrastructures, policies, waste disposal systems, pollution, and access to services by citizens. These indicators measure how much a city is a greenness [10]. The green city indicators particularly divide into two-part; quantitative and qualitative indicators. Quantitative indicators are getting used to explain the three Green City dimensions, which the environmental quality dimension has the largest number of indicators. Qualitative indicators specifically are being used to evaluate the city's environmental policies [5]. The thirteen categories of indicators play an essential function in evaluating the greenness of a city, which are transport, air quality \& $\mathrm{CO}_{2}$, energy, water, green spaces, building, acoustic environment, education, equity, safety, health, and participation [5].

\section{Methodology}

As a sample for study, the Omid-e-Sabz Town has been taken a typical town for study. This research focus on the selection of indicators, suggested strategies, and environmental impact. The first methodology was to identify the indicators that studied in the other research paper. After identifying, the indicators are selected based on political, economic, ecological, and other situations. Besides, some new indicators have been created by author for better illustration of some categories. Secondly, we have suggested some applicable strategies that will have important effect on the smart and sustainable cities indicators. We proposed the strategies based on the political, social, cultural, and economic situation which cost of some strategies are estimated. Moreover, we have measured the environmental impact of the strategies.

\section{Electricity Consumption (Two Months)}

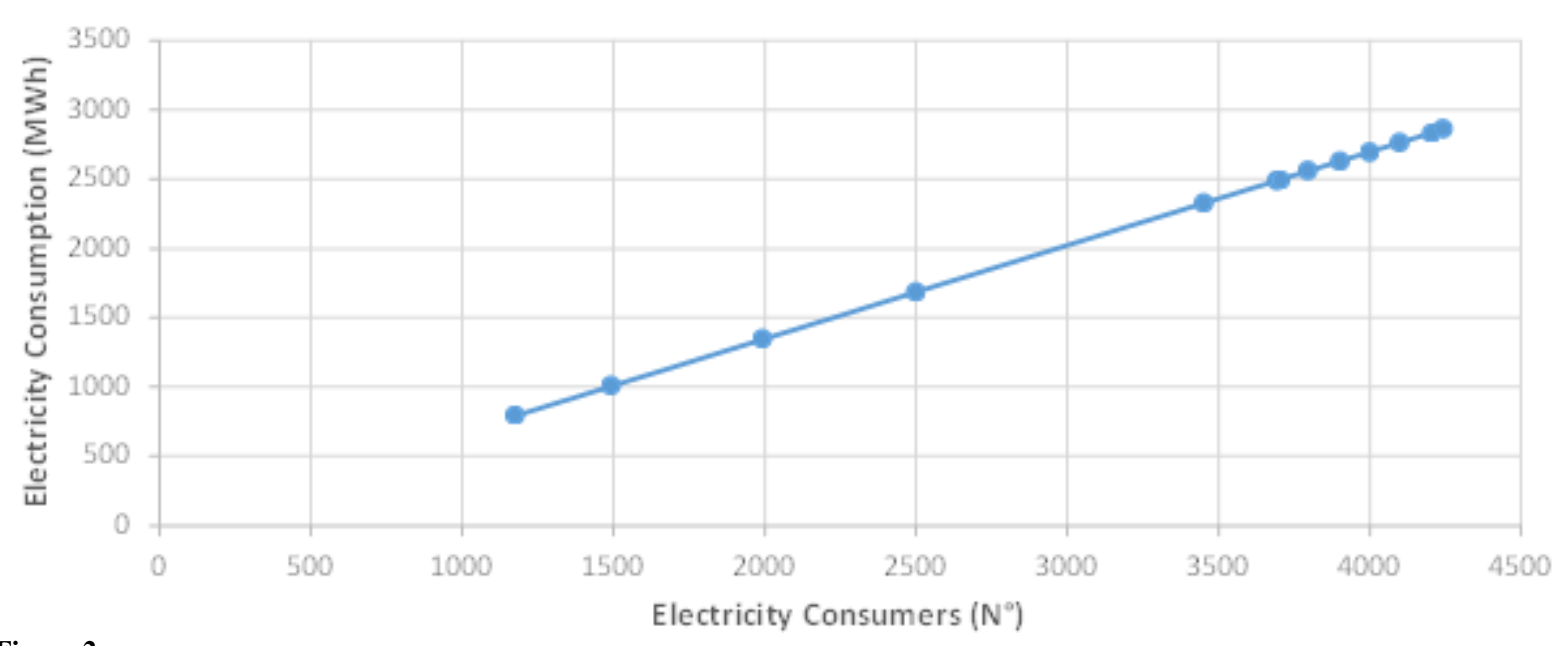

Figure-2.

Linear model electricity consumption relative to consumers.

In recent years, Kabul city has sort of challenges. These challenges can be solved by one procedure that is sustainable and smart cities. Water has emerged as a hot topic from a few years ago. The dearth of potable water is a critical task for Kabul residents. According to the Afghanistan National Environmental Protection Agency (NEPA), 70\% of groundwater had been contaminated in Kabul city [11]. It means that $70 \%$ of Kabul population does not have access to clean potable water. Electricity shortage can be seen every year during winter. DABS does promise to solve this problem every year, but they could not. Pollution that is being caused by emissions of $\mathrm{CO}_{2}$, NOx, and SOx from transport, stove, crowded, and the uncompleted combustion of conventional energy has placed resident's life to a vital health threat. Therefore, we have studied smart and sustainable cities as a solution to these problems. In this study, the combined methods of research (quantitative, qualitative) had been used. The accumulating of data is being accomplished by two approaches. First, a couple of information that was being needed about Omid-e-Sabz Town gathers from Kabul municipality (KM) and the 
office of Omid-e-Sabz Town. Furthermore, the statistics about electricity consumption and electricity load of Omid-e-Sabz Town collected from DABS. Second, some data accrued from Articles, e-books, Conference papers, Reports, and Environmental Protection Agency (EPA).

We had electrical data of Omid-e-Sabz from DABS for 2015 but we need an update data that we could not find it. Therefore, we used a linear model for estimating the power consumption of 4,250 consumers of Omid-e-Sabz Town. In figure, we can see that the power consumption is $2,866 \mathrm{MWh} / 2$-months for 4,250 consumers. We estimated that we will have 4,250 consumers in 2020. Figure 2 shows the linear model of electricity consumption relative to consumers.

\section{Result and Discussion}

The result illustrates three crucial findings: first, there are hundreds of indicators of the sustainable and smart city that has been used around the world. In this study, 106 indicators were selected or created to apply in the Omid-e-Sabz Town. These Indicators also can be applicable for Kabul City because Omid-e-Sabz town was a trail. Second, applicable strategies had been proposed if we transform the township into smart and sustainable cities. Finally, the effect of this transformation on environment has been measured.

\subsection{Indicators}

Indicators are the characteristics that define sustainable and smart cities. The indicators are the base for transformation to sustainable and smart cities. In this research, we have collected and studied more than 400 indicators. From 400 indicators, the 115 indicators were the sustainable indicators while the remaining were the smart city indicators. We have studied each indicator one after the other which 106 applicable and suitable indicators have been selected and created based on culture, weather, society, and political condition at Kabul city. We have divided the indicators into three-part. First, the indicators that are perceived as they are existing in the city. Second, the indicators that we believed they did not use before in this town. Furthermore, these indicators are retrieved from other journal papers or reports. Finally, the indicators that we have prepared because are not found in journal papers or reports.

The 55 indicators are perceived to existing in the town. In Table 1, we can see the 55 indicators that are perceived they existing in this town. The second column states the indicators name while the third and fourth column represent the sustainable city categories and smart city dimensions that describe an indicator has effect on which categories. The unit for each indicator is shown at the last column.

Table-1.

$\underline{\text { Smart Sustainable Cities Indicators that have been used in the Omid-e-Sabz Town [5, 12-16]. }}$

\begin{tabular}{|c|c|c|c|c|}
\hline No & Indicators Name & Sustainable & Smart & Unit \\
\hline 1 & Average annual concentration of $\mathrm{PM}_{2.5}$ & Air Quality & Smart Environment & $\mu \mathrm{g} / \mathrm{m}^{3}$ \\
\hline 2 & Average annual concentration of $\mathrm{PM}_{10}$ & Air Quality & Smart Environment & $\mu \mathrm{g} / \mathrm{m}^{3}$ \\
\hline 3 & Average annual concentration of SOx & Air Quality & Smart Environment & $\mu \mathrm{g} / \mathrm{m}^{3}$ \\
\hline 4 & Average annual concentration of NOx & Air Quality & Smart Environment & $\mu \mathrm{g} / \mathrm{m}^{3}$ \\
\hline 5 & average annual concentration of $\mathrm{O}_{3}$ & Air Quality & Smart Environment & $\mu \mathrm{g} / \mathrm{m}^{3}$ \\
\hline 6 & $\mathrm{CO}_{2}$ Intensity & $\mathrm{CO}_{2}$ & Smart Environment & Grams/ GDP \\
\hline 7 & $\mathrm{CO}_{2}$ Emissions per capita & $\mathrm{CO}_{2}$ & Smart Environment & $\begin{array}{l}\mathrm{t} \quad \mathrm{CO}_{2} \\
\text { Emissions/ } \\
\text { person }\end{array}$ \\
\hline 8 & Total $\mathrm{CO}_{2}$ emissions per KWh electricity Consumed & $\mathrm{CO}_{2}$ & Smart Environment & $\begin{array}{l}\mathrm{t} \mathrm{CO}_{2} / \\
\mathrm{KWh}\end{array}$ \\
\hline 9 & Tons of $\mathrm{CO}_{2}$ emissions from transportation & $\mathrm{CO}_{2}$ & Smart Environment & $\begin{array}{l}\mathrm{t} \quad \mathrm{CO}_{2} \quad / \\
\text { vehicle }\end{array}$ \\
\hline 10 & Tons of $\mathrm{CO}_{2}$ emissions from waste & $\mathrm{CO}_{2}$ & Smart Environment & $\begin{array}{l}\mathrm{t} \mathrm{CO}_{2} / \mathrm{t} \\
\text { Solid waste }\end{array}$ \\
\hline 11 & Share of population exposed to noise pollution & Acoustic & Smart Environment & $\%$ \\
\hline 12 & Average Annual Electricity consumption & Energy & Smart Environment & MWh/ year \\
\hline 13 & KWh of electricity use by residential sector & Energy & Smart Environment & $\mathrm{kWh}$ \\
\hline 14 & KWh of electricity use by commercial sector & Energy & Smart Environment & $\mathrm{kWh}$ \\
\hline 15 & KWh of electricity use by city facilities & Energy & Smart Environment & $\mathrm{kWh}$ \\
\hline 16 & $\begin{array}{l}\text { Annual average number of electrical interruptions per } \\
\text { year, per customer }\end{array}$ & Energy & Smart Environment & $\mathrm{N}^{\circ}$ \\
\hline 17 & Daily water consumption per capita & Water & Smart Living & lit/day \\
\hline 18 & Population with Access to potable water & Water & Smart Living & $\%$ \\
\hline 19 & Annual wastewater generated & Water & Smart Living & liters \\
\hline
\end{tabular}




\begin{tabular}{|c|c|c|c|c|}
\hline 20 & Number of sewer spills & Water & Smart Living & $\mathrm{N}^{\circ}$ \\
\hline 21 & Percent of Water system leakages & Water & Smart Living & $\%$ \\
\hline 22 & Percentage of city's wastewater receiving treatment & Water & Smart Living & $\%$ \\
\hline 23 & Total Municipal Waste production & Waste & Smart Environment & ton/yr \\
\hline 24 & Total solid waste generation per capita & Waste & Smart Environment & ton/ capita \\
\hline 25 & $\begin{array}{l}\text { Share of the population with municipal solid waste } \\
\text { (MSW) collection }\end{array}$ & Waste & Smart Environment & $\%$ \\
\hline 26 & Hazardous waste generation per capita & Waste & Smart Environment & ton/ capita \\
\hline 27 & Amount of Household Waste generated per capita & Waste & Smart Environment & ton/yr \\
\hline 28 & $\begin{array}{l}\text { Percent of households within } 1 \mathrm{~km} \text { of a park or } \\
\text { recreational open space }\end{array}$ & Green Areas & Smart Environment & $\%$ \\
\hline 29 & Percent of green space added & Green Areas & Smart Environment & $\%$ \\
\hline 30 & $\begin{array}{l}\text { Percentage of population with access to improved } \\
\text { sanitation }\end{array}$ & $\begin{array}{l}\text { Health and } \\
\text { Safety }\end{array}$ & Smart Living & $\%$ \\
\hline 31 & Suicide rate & $\begin{array}{l}\text { Health and } \\
\text { Safety }\end{array}$ & Smart People & $\mathrm{N}^{\circ}$ \\
\hline 32 & Number of murders & $\begin{array}{l}\text { Health and } \\
\text { Safety }\end{array}$ & Smart People & $\mathrm{N}^{\circ}$ \\
\hline 33 & Number of deaths related fire & $\begin{array}{l}\text { Health and } \\
\text { Safety }\end{array}$ & Smart Living & $\mathrm{N}^{\circ}$ \\
\hline 34 & $\begin{array}{l}\text { Response time for emergency response services from } \\
\text { initial call }\end{array}$ & $\begin{array}{l}\text { Health and } \\
\text { Safety }\end{array}$ & Smart People & $\min$ \\
\hline 35 & Response time for fire department from initial call & $\begin{array}{l}\text { Health and } \\
\text { Safety }\end{array}$ & Smart Living & $\min$ \\
\hline 36 & Response time for police department from initial call & $\begin{array}{l}\text { Health and } \\
\text { Safety }\end{array}$ & Smart Living & $\min$ \\
\hline 37 & Violent crime rate & $\begin{array}{l}\text { Health and } \\
\text { Safety }\end{array}$ & Smart People & $\%$ \\
\hline 38 & $\begin{array}{l}\text { Share of peoples connected to the internet by any } \\
\text { access method }\end{array}$ & Education & Smart Living & $\%$ \\
\hline 39 & Percent of inhabitants travelling on public transport & Transport & Smart Mobility & $\%$ \\
\hline 40 & $\begin{array}{l}\text { Average number of vehicles (cars and motorbikes) per } \\
\text { household }\end{array}$ & Transport & Smart Mobility & $\mathrm{N}^{\circ}$ \\
\hline 41 & $\mathrm{CO}_{2}$ equivalent production from transport & Transport & Smart Mobility & ton/yr \\
\hline 42 & Percent of population Foreign language skills & Education & Smart People & $\%$ \\
\hline 43 & Participation in voluntary work & Participation & Smart People & $\%$ \\
\hline 44 & Percentage of young & & Smart People & $\%$ \\
\hline 45 & Fertility rate & & Smart Governance & $\%$ \\
\hline 46 & Number of business & & Smart Economy & $\mathrm{N}^{\circ}$ \\
\hline 47 & Employment rate & & Smart Economy & $\%$ \\
\hline 48 & Unemployment rate & & Smart Economy & $\%$ \\
\hline 49 & Percentage of city population Living in poverty & & Smart Economy & $\%$ \\
\hline 50 & Tax collected as a percentage of tax billed & & Smart Economy & $\%$ \\
\hline 51 & Life expectancy & $\begin{array}{l}\text { Health and } \\
\text { Safety }\end{array}$ & Smart Living & years \\
\hline 52 & $\begin{array}{l}\text { Percentage of female school-aged population enrolled } \\
\text { in schools }\end{array}$ & Education & Smart Living & $\%$ \\
\hline 53 & Percentage of students completing primary education & Education & Smart Living & $\%$ \\
\hline 54 & $\begin{array}{llll}\begin{array}{l}\text { Percentage of students } \\
\text { education }\end{array} & \text { completing secondary } \\
\end{array}$ & Education & Smart Living & $\%$ \\
\hline 55 & Percentage of higher education's degrees & Education & Smart Living & $\%$ \\
\hline
\end{tabular}

We believed that 29 indicators are not used before in this town. Besides, their existence is also not perceived in the town. These indicators have been added for the better implementation of smart and sustainable cities. These indicators are shown in the Table 2. 
Table-2.

Smart Sustainable Cities Indicators that are not used in the Omid-e-Sabz Town $[\mathbf{5 , 1 2 - 1 5 , 1 7 , 1 8 ]}$

\begin{tabular}{|c|c|c|c|c|}
\hline No & Indicators Name & Sustainable & Smart & Unit \\
\hline 1 & Percentage of citizens living within $300 \mathrm{~m}$ of quiet areas & Acoustic & $\begin{array}{l}\text { Smart } \\
\text { Environment }\end{array}$ & $\%$ \\
\hline 2 & Average annual Renewable Energy Consumption & Energy & $\begin{array}{l}\text { Smart } \\
\text { Environment }\end{array}$ & $\mathrm{MJ} /$ year \\
\hline 3 & KWh energy savings from energy efficiency & Energy & $\begin{array}{l}\text { Smart } \\
\text { Environment }\end{array}$ & $\mathrm{kWh}$ \\
\hline 4 & $\mathrm{~kW}$ peak energy reduction from energy efficiency & Energy & $\begin{array}{l}\text { Smart } \\
\text { Environment }\end{array}$ & $\mathrm{kW}$ \\
\hline 5 & Energy Intensity & Energy & $\begin{array}{l}\text { Smart } \\
\text { Environment }\end{array}$ & MJ/GDP \\
\hline 6 & Annual total electricity consumption per capita & Energy & $\begin{array}{l}\text { Smart } \\
\text { Environment }\end{array}$ & $\begin{array}{l}\mathrm{kWh} / \\
\text { person/yr }\end{array}$ \\
\hline 7 & Numbers of registered cars & Transport & Smart Mobility & $\mathrm{N}^{\circ}$ \\
\hline 8 & Kilometers of cycle paths and lanes & Transport & Smart Mobility & $\mathrm{km}$ \\
\hline 9 & Average age of car (total and by type) & Transport & Smart Mobility & years \\
\hline 10 & Satisfaction with access to public transport & Transport & Smart Mobility & $\%$ \\
\hline 11 & Satisfaction with quality of public transport & Transport & Smart Mobility & $\%$ \\
\hline 12 & Number of Electrical Vehicle (EV) charging stations & Transport & Smart Mobility & $\mathrm{N}^{\circ}$ \\
\hline 13 & Number of rechargers at EV charging stations & Transport & Smart Mobility & $\mathrm{N}^{\circ}$ \\
\hline 14 & $\mathrm{kWh}$ recharged in the EV charging stations & Transport & Smart Mobility & $\mathrm{kWH}$ \\
\hline 15 & $\begin{array}{l}\text { Proportion of public parking connected to the parking } \\
\text { management system }\end{array}$ & Transport & Smart Mobility & $\%$ \\
\hline 16 & $\begin{array}{l}\text { Proportion of traffic lights connected to the traffic } \\
\text { management system }\end{array}$ & Transport & Smart Mobility & $\%$ \\
\hline 17 & Satisfaction with quality of e-governance service & & $\begin{array}{l}\text { Smart } \\
\text { Governance }\end{array}$ & \\
\hline 18 & Number of web visitors per year & Education & $\begin{array}{l}\text { Smart } \\
\text { Governance }\end{array}$ & $\mathrm{N}^{\circ}$ \\
\hline 19 & Information services for residents & Education & $\begin{array}{l}\text { Smart } \\
\text { Governance }\end{array}$ & \\
\hline 20 & Satisfaction with quality of health system & $\begin{array}{l}\text { Health and } \\
\text { Safety }\end{array}$ & Smart Living & \\
\hline 21 & Satisfaction with access to educational system & Education & Smart Living & \\
\hline 22 & Satisfaction with quality of educational system & Education & Smart Living & \\
\hline 23 & Improved cyber security & & Smart Living & $\%$ \\
\hline 24 & Improved data privacy & & Smart Living & $\%$ \\
\hline 25 & Increased environmental awareness & Education & Smart Living & $\%$ \\
\hline 26 & Satisfaction with fight against corruption & & $\begin{array}{l}\text { Smart } \\
\text { Governance }\end{array}$ & \\
\hline 27 & Percentage of population having a Master /Ph.D. degree & Education & Smart People & $\%$ \\
\hline 28 & Mortality of underage five & $\begin{array}{l}\text { Health and } \\
\text { Safety }\end{array}$ & Smart Living & $\mathrm{N}^{\circ}$ \\
\hline 29 & $\begin{array}{l}\text { Proportion of municipal solid waste (MSW) that is } \\
\text { sorted and recycled (total and by type of waste e.g. } \\
\text { paper, glass, batteries, PVC, bottles, metals) }\end{array}$ & Waste & $\begin{array}{l}\text { Smart } \\
\text { Environment }\end{array}$ & $\%$ \\
\hline
\end{tabular}

We have prepared a few indicators of smart and sustainable cities to show the contribution of important categories that do not exist in the journals and reports. We have prepared 22 indicators based on economic, political, cultural, and weather conditions in Afghanistan. Furthermore, these indicators are only applicable in Afghanistan. The 22 indicators have been shown in Table 3. 
Table-3.

Smart and Sustainable Cities Indicators that are prepared for the Omid-e-Sabz Town.

\begin{tabular}{|c|c|c|c|c|}
\hline No & Indicators Name & Sustainable & Smart & Unit \\
\hline 1 & Transferred building into green buildings & Buildings & Smart Environment & $\mathrm{N}^{\circ}$ \\
\hline 2 & Annual number of trees planted & Green Areas & Smart Environment & $\mathrm{N}^{\circ}$ \\
\hline 3 & Number of total trees & Green Areas & Smart Environment & $\mathrm{N}^{\circ}$ \\
\hline 4 & Number of Green building & Buildings & Smart Environment & $\mathrm{N}^{\circ}$ \\
\hline 5 & Number of electric vehicles in city & Transport & Smart Mobility & $\mathrm{N}^{\circ}$ \\
\hline 6 & Percentage of diesel cars in total vehicles cars & Transport & Smart Mobility & $\%$ \\
\hline 7 & Total number of cars run by hybrid & Transport & Smart Mobility & $\mathrm{N}^{\circ}$ \\
\hline 8 & Number of Pharmacies & $\begin{array}{l}\text { Health } \\
\text { Safety }\end{array}$ & Smart Living & $\mathrm{N}^{\circ}$ \\
\hline 9 & Annual Total gas consumption & Energy & Smart Environment & $\mathrm{kg} / \mathrm{yr}$ \\
\hline 10 & Annual total wood use for Heating & Energy & Smart Environment & $\mathrm{kg} / \mathrm{yr}$ \\
\hline 11 & Annual total Coal use for heating & Energy & Smart Environment & $\mathrm{kg} / \mathrm{yr}$ \\
\hline 12 & Annual total gas use for heating & Energy & Smart Environment & $\mathrm{kg} / \mathrm{yr}$ \\
\hline 13 & Annual total electricity use for heating & Energy & Smart Environment & $\mathrm{kWh} / \mathrm{yr}$ \\
\hline 14 & Annual total electricity use for cooling & Energy & Smart Environment & $\mathrm{kWh} / \mathrm{yr}$ \\
\hline 15 & Annual total wood use & Energy & Smart Environment & $\mathrm{kg} / \mathrm{yr}$ \\
\hline 16 & Annual total other type of energy use & Energy & Smart Environment & $\begin{array}{ll}\mathrm{kg} & \text { or } \\
\mathrm{lit} / \mathrm{yr} & \\
\end{array}$ \\
\hline 17 & Liters of water purchased per capita & Water & Smart Living & $\begin{array}{l}\text { lit/day/ } \\
\text { person }\end{array}$ \\
\hline 18 & Number of hospitals & $\begin{array}{l}\text { Health } \\
\text { Safety }\end{array}$ & Smart Living & $\mathrm{N}^{\circ}$ \\
\hline 19 & Number of fuel station for cars & Transport & Smart Mobility & $\mathrm{N}^{\circ}$ \\
\hline 20 & Percentage of population without income & & Smart Economy & $\%$ \\
\hline 21 & Female employment & Equity & Smart Economy & $\mathrm{N}^{\circ}$ \\
\hline 22 & $\begin{array}{l}\text { Percent inhabitant have access to education } \\
\text { system }\end{array}$ & Education & Smart Living & $\%$ \\
\hline
\end{tabular}

\subsection{Strategies}

We have suggested some strategies for implementation in this town. Moreover, we calculated the environmental effect in section 4.3. These strategies would affect directly into indicators that shows the change towards the sustainable and smart city. In this section, we estimate some data of strategies along with suggesting of these strategies. The primary proposed strategy is the Photovoltaic (PV) system. PV system has been proposed for energy utilization because it is clean energy. We have taken some assumption for estimation of PV system. The assumptions are cost of equipment's and number of consumer in 2020. Furthermore, we assume that all PV system will be on-grid system. We suggest 8 MW ongrid rooftop PV system because the energy consumption will reduce after implementation of energy efficiency strategy. Moreover, the solar heat collector has been recommended for heating, while energy efficiency also has been suggested to apply because it will control the heat gain and heat loss. We have taken two assumptions for solar heat collector and energy efficiency. We assumed that every house need 3 solar heat collector with 300-liter capacity and the cost is about $\$ 650$. Besides, we assumed all buildings of this town is three floor building because it will take lots of time to estimate insulation for all types of buildings. Energy Efficiency cost of a typical three floor building is around 18,350 USD and it will save up to $46 \%$ of energy [19]. Thus, we take assumption that all buildings of this town will cost the same price and will save the same percentage for energy efficiency. We have shown the details of these three strategies in the Table 4.

Table-4.

Details of Energy Strategies for Smart Sustianble Cities.

\begin{tabular}{c|c|c|c|c}
\hline Strategy Name & No Households & Size & Area & Total Cost $(\$)$ \\
\hline PV System & 4,250 & $8 \mathrm{MW}$ & 40 jerib & 6.12 Million \\
\hline Solar Collector & 4,250 & $3,825,000 \mathrm{~L}$ & 25.5 jerib & 8.3 Million \\
\hline Energy Efficiency & 4,250 & Three Floor & & 78 Million \\
\hline
\end{tabular}

We have suggested two strategies for waste because we have huge amounts of waste in Kabul. Hence, we suggested anaerobic biogas digester and waste collection and recycling for waste management system. Kabul city generate 0.71 $\mathrm{kg} / \mathrm{day} /$ person waste that 0.43 is reusable, 0.28 is recyclable, and 0.29 is the landfilling waste [20]. In this town, we assumed the max waste generation that is about 19.5 ton per day, which 8.4 ton/day is reusable in the biogas digesters, 5.5 ton/day is recyclable in the waste recycling plant, and 5.7 ton/day is the landfilling waste. We have suggested three strategies for water management system. The rainwater storage well, Decentralized Wastewater System (DEWATS), and Potable water piping system are the suggested strategies. The rainwater storage well strategy is to make a well with depth of 6 to $10 \mathrm{~m}$ and with diameter of $1 \mathrm{~m}$ in every 400 to $700 \mathrm{~m}^{2}$ or at least 4,500 wells in this town. We assumed that $15 \%$ of 
rainwater will be caught in these wells. We suggested that water piping system must install for every house in this town to use from water because drilling well will bring drought in this town and Kabul. We assumed that 95\% households will use from potable water piping system because maybe some household don't use from this strategy. The wastewater management is very crucial for a city because it will decrease the water usage up to 50 percent. Therefore, we suggested the DEWATS system for wastewater treatment of this town. The assumption has been taken that every person generates 20 liters of sewage. The DEWATS capacity that required for this town is about $16,500 \mathrm{~m}^{3}$. Moreover, we assumed that DEWATS will treat $30 \%$ of wastewater. In Table 5, the description and size of these strategies are represented.

Table-5.

Waste and Water Strategies for Smart Sustainable Cities.

\begin{tabular}{|c|c|c|}
\hline Strategy Name & Description & Size \\
\hline $\begin{array}{l}\text { Anaerobic Biogas } \\
\text { Digester }\end{array}$ & $\begin{array}{l}\text { From } 0.71 \mathrm{~kg} / \mathrm{day} / \text { inhabitant waste generation, the } 0.43 \mathrm{~kg} / \mathrm{day} / \mathrm{inhabitant} \\
\text { is reusable in the biogas digester. We suggested } 2 \text { biogas digester. }\end{array}$ & $\begin{array}{l}8.4 \\
\text { ton/day }\end{array}$ \\
\hline $\begin{array}{l}\text { Waste Collection and } \\
\text { Recycling }\end{array}$ & $\begin{array}{l}\text { From } 0.71 \mathrm{~kg} / \mathrm{day} / \text { inhabitant waste generation, the } 0.28 \mathrm{~kg} / \mathrm{day} / \text { inhabitant } \\
\text { is recyclable in the waste recycling plant. }\end{array}$ & $\begin{array}{l}5.5 \\
\text { ton/day }\end{array}$ \\
\hline $\begin{array}{l}\text { Rainwater Storage } \\
\text { Well }\end{array}$ & $\begin{array}{l}\text { A well with depth of } 6 \text { to } 10 \mathrm{~m} \text { and diameter of } 1 \mathrm{~m} \text { will be drilled in } \\
\text { every } 400 \text { to } 700 \mathrm{~m}^{2} \text {. It will catch up to } 15 \% \text { of rainwater during a year. }\end{array}$ & $\begin{array}{l}4500 \\
\text { wells }\end{array}$ \\
\hline $\begin{array}{l}\text { Potable Water Piping } \\
\text { System }\end{array}$ & $\begin{array}{l}\text { A drinking water piping system from once central drill well to every } \\
\text { household for drinking water, cooking, and other usage. }\end{array}$ & $95 \%$ \\
\hline DEWATS & $\begin{array}{l}\text { The DEWATS strategy will treat wastewater for irrigation and usage in } \\
\text { bathroom. It will treat } 30 \% \text { of wastewater. }\end{array}$ & $\begin{array}{l}16,500 \\
\mathrm{~m}^{3}\end{array}$ \\
\hline
\end{tabular}

We have suggested four strategies for transportation system. These strategies are public electric bus, electric vehicle (EV), on-grid solar charging station, and bike path. We have suggested electric bus for public transportation. It will decrease the traffic in the town. We assumed that 12 electric bus will be sufficient for public transportation in this town. Furthermore, we assumed that average cost of each electric bus is $\$ 750,000$. Thus, the total cost of this strategy will be around 9 million USD. We assumed that one person from every 30 persons has car in this town. Therefore, the total private car is 916 in this town. We assumed that $25 \%$ of those who have cars will change their vehicle to electrical vehicle because the high cost of electrical vehicle. Besides, we assumed that cost of an electrical vehicle be around 45,000 USD. We have suggested the on-grid solar charging station for charging the electric vehicle. We proposed 8 on-grid solar charging station. We take assumption that every on-grid solar charging station will cost 30,000 USD. The people from $14-45$ ages will have been encouraged to use from the bike for transportation in this town. The bike path has assumed to construct $40 \mathrm{~km}$ around the town. Besides, we assumed that the construction cost of $1 \mathrm{~km}$ bike path will be around 50,000 USD. Table 6 shows the quantity, unit cost, and total cost of these strategies.

Table-6.

Transportation Strategies of Smart Sustainable Cities.

\begin{tabular}{l|c|c|c}
\hline Strategy Name & QTY & Unit Cost & Total Cost \\
\hline Public Electric Bus & 12 & $\$ 750,000$ & $\$ 9$ Million \\
\hline Electric Vehicle & 230 & $\$ 45,000$ & $\$ 10.35$ Million \\
\hline On-grid Solar Charging Station & 8 & $\$ 30,000$ & $\$ 240,000$ \\
\hline Bike path & $40 \mathrm{~km}$ & $\$ 50,000$ & $\$ 2$ million \\
\hline
\end{tabular}

We have suggested two strategies for green areas. The green building and vertical garden are the proposed strategies. Green building strategy can reduce the pollution and bring aesthetic to the environment. Besides, it is a solution for climate change and global warming. Vertical Garden is a new idea that comes in the world. It constructs the vertical building that can produce a few times more food than the food product in the same amount of land. These two strategies are more helpful when we transform Kabul city to a smart sustainable city. Therefore, we suggested these strategies first in this town like a prototype strategy. In table, you can see these strategies along with description. In Table 7, we have described these strategies in some detail.

Table-7.

Green Areas Strategies for Smart Sustainable Cities.

\begin{tabular}{|c|c|}
\hline Strategy Name & Description \\
\hline Green Building & $\begin{array}{l}\text { The cost of green building is a little bit high relative to conventional buildings but it can } \\
\text { save energy and absorb the GHG that have value more than it is cost. We suggested that at } \\
\text { least } 16 \% \text { buildings change to green building in this town. }\end{array}$ \\
\hline Vertical Garden & $\begin{array}{l}\text { The vertical garden will produce vegetables and fruits for inhabitants of this town. We } \\
\text { proposed that } 4 \text { vertical garden built at an area of } 2,400 \mathrm{~m}^{2} \text { in the town. }\end{array}$ \\
\hline
\end{tabular}

The last three suggested strategies are closed-circuit television (CCTV) security camera, internet of things (IoT), and ICT. These strategies are very crucial for a smart city. These are the base for transformation to a smart city. The ICT 
strategy is helpful for smart education system because the world goes faster on innovation of new technologies. Therefore, it is important to learn and work with these technologies. On the other hand, IoT strategy is the base of all smart sustainable cities because the town will not be a smart city without this strategy. It connects all systems on one control system. Besides, it will transfer data from one system to another for a command. The description of these strategies have been shown in Table 8 .

Table-8.

Smart Strategies for Smart Sustainable Cities.

\begin{tabular}{l|l} 
Smart Strategies for Smart Sustainable Cities. \\
\hline Strategy Name & Description \\
\hline CCTV Security Camera & $\begin{array}{l}\text { The CCTV has been suggested to install all over town. It will provide the monitoring for } \\
\text { security purpose. }\end{array}$ \\
\hline ICT & $\begin{array}{l}\text { We suggested to provide ICT for every student. Thus, they can learn modern and smart } \\
\text { technologies. }\end{array}$ \\
\hline IoT & $\begin{array}{l}\text { IoT have been proposed to provide for all inhabitants. Besides, IoT will be connected to } \\
\text { all technologies. }\end{array}$ \\
\hline
\end{tabular}

\subsection{Environmental Impact}

The sustainable and smart city is the mixture of several solutions for the reduction within the GHG emissions. The transforming of this town into a green and smart town will cut GHG emissions and other pollutions that will affect the climate change and global warming in a small scale. We have measured the environmental impact of some strategies but we have taken some assumptions for data. The first assumption is the $\mathrm{CO}_{2}$ emission for all strategies based on the fuel consumption type or carbon dioxide absorption per area like in column 4 table 9 . We also assumed that 75 wh is needed to heat 1 liter of water. Besides, we calculated the biogas production and $\mathrm{CO}_{2}$ emission from an online calculator in the RENERGON website [21]. Furthermore, we assumed that calculation from this website is nearly accurate for estimation of $\mathrm{CO}_{2}$ emission. We compare electric bus and electric car to diesel bus and petrol car. We have taken assumption that bus will travel 19,300 km/year and car will travel 12,250 km/year. Besides, we assumed the fuel consumption $32 \mathrm{~L} / 100 \mathrm{~km}$ for bus and $9 \mathrm{~L} / 100 \mathrm{~km}$ for car. We have calculated the carbon dioxide emission for all these strategies which except biogas that emit carbon dioxide other strategies reduce these amount of carbon dioxide production in a year. The total annual $\mathrm{CO}_{2}$ emission from all strategies with description have been shown in Table 9.

Table-9.

Annual $\mathrm{CO}_{2}$ Emission from Strategies.

\begin{tabular}{|c|c|c|c|c|}
\hline Strategy Name & Description & $\begin{array}{l}\text { Energy } \\
\text { Consumption }\end{array}$ & $\mathrm{CO}_{2}$ Emission & $\begin{array}{l}\text { Total Annual } \\
\text { Tonne of } \mathrm{CO}_{2} \\
\text { emission }\end{array}$ \\
\hline PV System & $8 \mathrm{MW}$ of On-grid PV Panel & $\begin{array}{l}13,705,830 \\
\text { kwh }\end{array}$ & $0.22 \mathrm{~kg} / \mathrm{kwh}$ & $-3,015.28$ \\
\hline Solar Collector & $\begin{array}{l}\text { 12,750 Solar Collector of } 300 \text { liters } \\
\text { for } 4,250 \text { Consumers. }\end{array}$ & $\begin{array}{l}97,728,750 \\
\text { kwh }\end{array}$ & $0.22 \mathrm{~kg} / \mathrm{kwh}$ & $-21,500.33$ \\
\hline Energy Efficiency & $46 \%$ of energy saving & $7,910,160 \mathrm{kwh}$ & $0.35 \mathrm{~kg} / \mathrm{kwh}$ & $-2,768.56$ \\
\hline $\begin{array}{l}\text { Anaerobic Biogas } \\
\text { Digester }\end{array}$ & $\begin{array}{l}\text { Two biogas digester for } 8.4 \text { ton of } \\
\text { waste per day. }\end{array}$ & $\begin{array}{l}82,782,000 \\
\text { liter of biogas }\end{array}$ & $0.002 \mathrm{~kg} / \mathrm{l}$ & +165.56 \\
\hline Public Electric Bus & $\begin{array}{l}12 \text { electrical bus that is alternative for } \\
\text { diesel bus. }\end{array}$ & $\begin{array}{l}74,112 \text { liter of } \\
\text { diesel }\end{array}$ & $2.68 \mathrm{~kg} / \mathrm{l}$ & -198.62 \\
\hline Electric Vehicle & $\begin{array}{l}230 \text { electric car which is alternative } \\
\text { for petrol car. }\end{array}$ & $\begin{array}{ll}253,575 & \text { liter } \\
\text { of petrol }\end{array}$ & $2.31 \mathrm{~kg} / 1$ & -585.76 \\
\hline Green Building & $\begin{array}{l}680 \text { green building with area of at } \\
\text { least } 400 \mathrm{~m}^{2} \text {. }\end{array}$ & & $5.9 \mathrm{~kg} / \mathrm{m}^{3}$ & $-1,604.8$ \\
\hline Vertical Garden & 4 vertical garden with area of $600 \mathrm{~m}^{2}$ & & $4.95 \mathrm{~kg} / \mathrm{m}^{3}$ & -11.88 \\
\hline
\end{tabular}

We can see the annual $\mathrm{CO}_{2}$ emissions from all strategies in column five of Table 9. The minus sign represents the reduction amount of $\mathrm{CO}_{2}$ by these strategies. The plus sign shows the carbon emission from biogas burring as gas in the households. As we can see from Figure 3, the solar collector contributes mostly on $\mathrm{CO}_{2}$ reduction which is followed by PV system, energy efficiency, and green building. Figure 4 shows the annual predication of $\mathrm{CO}_{2}$ emissions till 2050. 


\section{$\mathrm{CO}_{2}$ Emissions from Strategies}

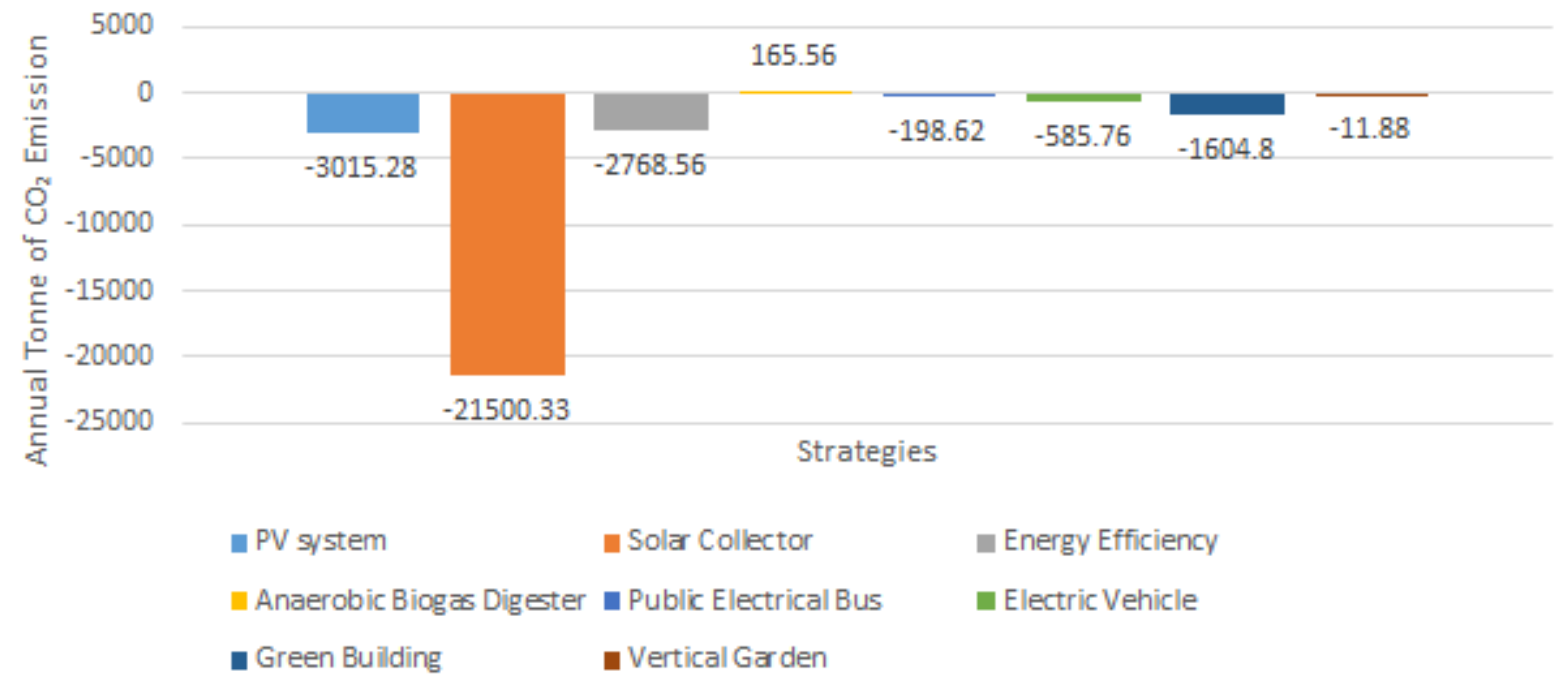

Figure-3.

Contribution chart of carbon dioxide emission from different strategies.

\section{Annual $\mathrm{CO}_{2}$ Emission Predication Till 2050}

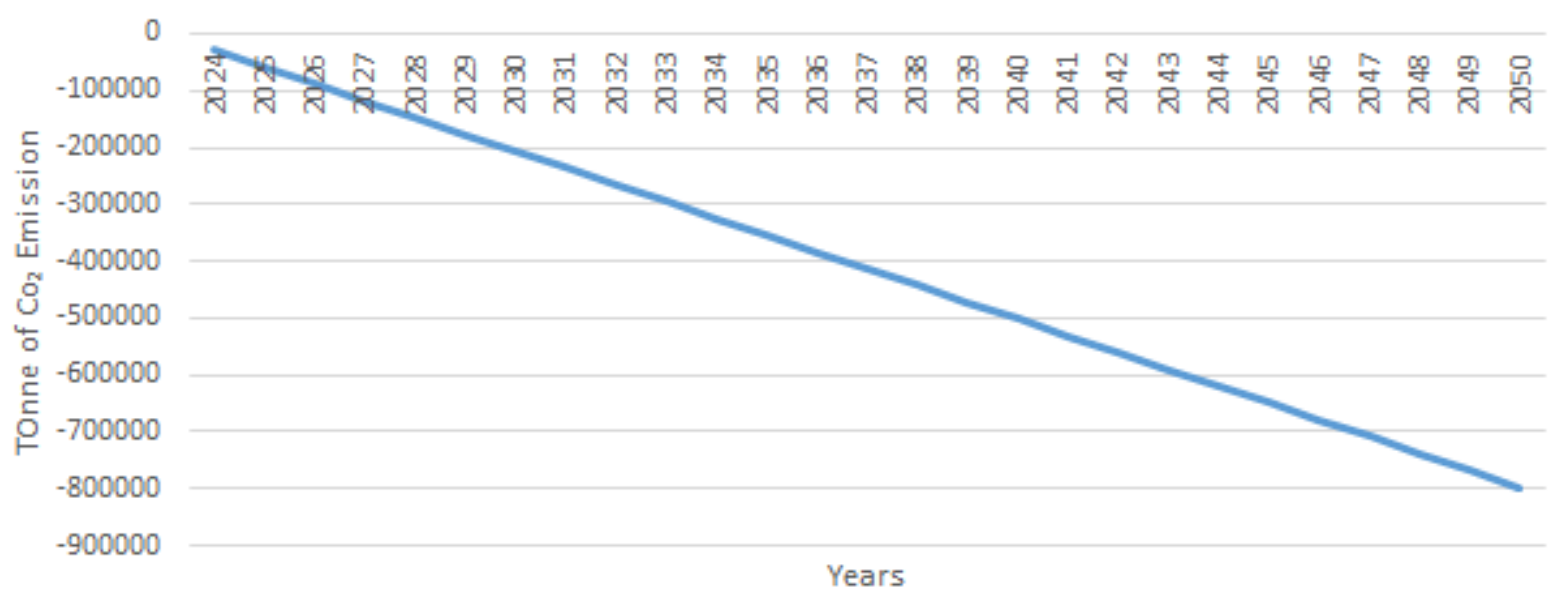

Figure-4.

Annual Carbon Dioxide Predication Till 2050.

\section{Conclusion}

In this research, the study has been completed on transforming the Omid-e-Sabz Town into a sustainable and smart town. Omid-e-Sabz town that is located inside Kabul city has the capacity 27,500 inhabitants. The research has been carried out on indicators selection, suggested strategies, and environmental impacts of strategies of the smart sustainable city, which from more than 400 indicators 106 indicators have been selected and created. On the other hand, 17 applicable and feasible strategies have been proposed for this transforming. Furthermore, the environmental impact of strategies has been measured. As a result, 29,519.67 tons of carbon dioxide have been reduced by implementation of this project.

\section{References}

[1] Kabul Municipality, "Omid-e-Sabz town map and data. Kabul," 2018.

[2] Da Afghanistan Breshna Sherkat, "Peak demand power and supply power. Kabul," 2018.

[3] Da Afghanistan Breshna Sherkat (DABS), "Clarification about Kabul electricity. Retrieved from https://www.facebook.com/DABS.AFG/videos/1562020383991091 [Accessed 10 March 2021]," 2021.

[4] Da Afghanistan Breshna Sherkat, "Omid-e-Sabz load demand and electricity consumption. Kabul," 2015.

[5] R. Pace, G. Churkina, and M. Rivera, "How green is a "green city"? A review of existing indicators and approaches," IASS Working Paper, 2016.

[6] C. Harrison, B. Eckman, R. Hamilton, P. Hartswick, J. Kalagnanam, J. Paraszczak, and P. Williams, "Foundations for smarter cities," IBM Journal of Research and Development, vol. 54, pp. 1-16, 2010.

[7] M. Eremia, L. Toma, and S. Mihai, "The smart city concept in the 21st Century," Procedia Engineering, vol. 181, pp. 12-19, 2017. Available at: 10.1016/j.proeng.2017.02.357.

[8] G. C. Lazaroiu and M. Roscia, "Definition methodology for the smart cities model," Energy, vol. 47, pp. 326-332, 2012. Available at: 10.1016/j.energy.2012.09.028. 
[9] F. Purnomo and H. Prabowo, "Smart city indicators: A systematic literature review," Journal of Telecommunication, Electronic and Computer Engineering (JTEC), vol. 8, pp. 161-164, 2016.

[10] Science for Environment Policy, "Indicators for sustainable cities," In-Depth Report 12. Produced for the European Commission DG Environment by the Science Communication Unit, UWE, Bristol2018.

[11] S. Kazemi, "Blue Gold: The quest for household water in Kabul city. [Blog] Afghanistan Analysts Network. Retrieved from https://www.afghanistan-analysts.org/en/reports/economy-development-environment/blue-gold-the-quest-for-household-waterin-kabul-city/ [Accessed 17 March 2020]," 2018.

[12] D. Barar, B. Boman, L. Centell, L. Hammond, C. Hunt-Hernandez, E. Jackson, K. Johnson, S. Killoran, B. Kimura, R. Laveaga, D. Lee, F. Lyn, J. Masuda, M. Mejia, R. Olguin, U. Schmidt, G. Silva, and A. Sterling, Green city indicators report. Pasadena: City of Pasadena, 2009.

[13] OECD and ICLEI, Green city action plan. Tirana: European Bank for Reconstruction and Development, 2016.

[14] R. Carli, M. Dotoli, R. Pellegrino, and L. Ranieri, "Measuring and managing the smartness of cities: A framework for classifying performance indicators," in Proceedings - 2013 IEEE International Conference on Systems, Man, and Cybernetics, SMC 2013, 2013, pp. 1288-1293.

[15] International Organization for Standardization, "Sustainable cities and communities - indicators for city services and quality of life (ISO Standard No. 37120:2018)," 2018.

[16] O. Brilhante and J. Klaas, "Green city concept and a method to measure green city performance over time applied to fifty cities globally: Influence of GDP, population size and energy efficiency," Sustainability, vol. 10, p. 2031, 2018.

[17] P. Bosch and S. Jongeneel, "CITYkeys indicators for smart city projects and smart cities," 2017.

[18] P. F. Herrera and C. Fajardo, "A framework for measuring smart cities," presented at the ACM International Conference Proceeding Series, 2014.

[19] A. M. Ahmadi, N. R. Sabori, and M. Halim, "A typical design for energy-efficient building: A case study of zero energy building," in Repa Proceeding Series, 2020, pp. 22-31.

[20] Kabul Municipality, Solid waste audit in Kabul. Kabul: USAID, n.d.

[21] RENERGON - ANAEROBIC DIGESTION, "Biogas calculator - simulate energy potential and financial projections. Retrieved from https://www.renergon-biogas.com/en/biogas-calculator [Accessed 12 March 2021]," n.d. 